\title{
Radiopharmaceuticals drug interactions: a critical review
}

\author{
RALPH SANTOS-OLIVEIRA ${ }^{1}$, SHEILA W. SMITH ${ }^{2}$ and ANA MARIA A. CARNEIRO-LEÃO ${ }^{3}$ \\ ${ }^{1}$ Comissão Nacional de Energia Nuclear (CNEN), Serviço de Controle de Qualidade, Av. Prof. Luiz Freire, 200 \\ Cidade Universitária, 50740-540 Recife, PE, Brasil \\ ${ }^{2}$ Department of Pharmaceutical Health Service Research, School of Pharmacy and Medicine, University of Maryland \\ 220 Arch Street, $12^{\text {th }}$ floor, Room 01-226, 21201 Baltimore, Maryland, USA \\ ${ }^{3}$ Universidade Federal Rural de Pernambuco (UFRPE), Departamento de Morfologia e Fisiologia Animal \\ Rua Dom Manoel de Medeiros s/n, Dois Irmãos, 52171-030 Recife, PE, Brasil \\ Manuscript received on July 30, 2007; accepted for publication on August 25, 2008; \\ presented by ALEXANDER W.A. KELLNER
}

\begin{abstract}
Radiopharmaceuticals play a critical role in modern medicine primarily for diagnostic purposes, but also for monitoring disease progression and response to treatment. As the use of image has been increased, so has the use of prescription medications. These trends increase the risk of interactions between medications and radiopharmaceuticals. These interactions which have an impact on image by competing with the radiopharmaceutical for binding sites for example can lead to false negative results. Drugs that accelerate the metabolism of the radiopharmaceutical can have a positive impact (i.e. speeding its clearance) or, if repeating image is needed, a negative impact. In some cases, for example in cardiac image among patients taking doxirubacin, these interactions may have a therapeutic benefit. The incidence of drug-radiopharmaceuticals adverse reactions is unknown, since they may not be reported or even recognized. Here, we compiled the medical literature, using the criteria of a systematic review established by the Cochrane Collaboration, on pharmaceutical-drug interactions to provide a summary of documented interactions by organ system and radiopharmaceuticals. The purpose is to provide a reference on drug interactions that could inform the nuclear medicine staff in their daily routine. Efforts to increase adverse event reporting, and ideally consolidate reports worldwide, can provide a critically needed resource for prevention of drug-radiopharmaceuticals interactions.
\end{abstract}

Key words: radiopharmaceuticals, radiopharmacy, drug interaction, systematic review.

\section{INTRODUCTION}

Radiopharmaceuticals are used for two purposes. The most important, and most common, is their use as diagnostic tools in clinical medicine. Radiopharmaceuticals, in the form of a traced compound, are administered to a patient in order to observe physiological alterations or abnormal distribution in the body. Radiopharmaceuticals serve a purpose in research, both clinical and nonclinical, where they are used as tracers to observe or quantitate biochemical or physiological processes (Tewson and Krohn 1998).

Correspondence to: Ralph Santos Oliveira

E-mail: roliveira@cnen.gov.br
There is a considerable body of evidence that biodistribution and pharmacokinetics of radiopharmaceuticals may be altered by a variety of drugs, disease conditions, and in some cases, surgical procedures (Hesslewood and Leung 1994). Drs. Sampson and Hesslewood (1989), state that these unknown and unrecognized interactions of radiopharmaceuticals with other compounds can lead to a state of total disorder. For example, interactions that result in poor organ visualization may require repeating the procedure, thus resulting in a excess (unnecessary) irradiation of organs or if the interaction is unrecognized, it may result in misdiagnosis. Such misdiagnosis could delay appropriate treatment (e.g. a 
tumor is not visualized) or lead to unnecessary treatment (e.g. an interaction that creates spurious findings).

Adverse drug reactions are a major cause of morbidity and mortality. In the United States, an estimated number of 701,547 people are seen at emergency departments because of adverse drug effects (Budnitz et al. 2006). Adverse event reporting database provides no information on incidence, as events may not be recognized, and in many countries reporting is not mandatory. The incidence of drug-radiopharmaceutical interactions is unknown.

Unlike drugs given for therapeutic purposes, the literature suggests that radiopharmaceuticals rarely cause adverse reactions. A recently survey in Japan reported a rate of 1.3 events per 100,000 administrations (Kusabe et al. 2006). An European study, conducted approximately one decade earlier, reported a rate of 11 events per 100,000 administrations (95\% confidence limits 3.319.2) (Hesslewood and Keeling 1997). These relatively low rates of adverse events may be explained, at least partially, by the usually small mass of drug injected or ingested. Additionally, radiopharmaceuticals are typically administered only once or at very limited number of times to any given patient (Silberstein and Ryan 1996) limiting the potential for allergic reactions and events which might be caused by cumulative exposures. Finally, patients are typically screened prior to imaging for known risk factors.

The possibility, however, of adverse reaction to a radiopharmaceutical does exist (Hesslewood and Keeling 1997, Cordova et al. 1982). Adverse reaction reports may be sent to manufacturers, regulatory authorities, and/or published in the professional literature. While there may be a small number of reported cases, studies have demonstrated that only $10 \%$ or less of possible adverse reactions are actually reported (Keeling 1994). Also, if a reaction is not serious or life-threatening, reporting by the manufacturer to regulatory authorities may not be required (Keeling 1994).

Just as the incidence of adverse events associated with radiopharmaceuticals is unknown, so is the incidence of interactions between radiopharmaceuticals and prescription drugs. Any drug or chemical agent which alters the chemical identity of the tracer or alters the physiological status of the organ of interest could be ex- pected to alter the disposition of the radiopharmaceutical (Sampson 1993). Given the extent of prescription drug use, and particular trends toward polypharmacy, even if the individual risk of any interaction is low, the potential burden of drug-radiopharmaceutical interactions maybe substantial on a population basis. In this review, we summarize the available literature on drugradiopharmaceutical interactions by organ class.

\section{DRUG INTERACTIONS WITH RADIOPHARMACEUTICALS}

Over 400 articles have been published on incompatibilities between drugs and radiopharmaceuticals. Amongst the various factors that can affect biodistribution of radiopharmaceuticals, ingestion of drugs (e.g. prescription medications) is the most commonly reported factor (Sampson 1990). As much of the literature is based on case studies and nonclinical (laboratory) experiments, there is little objective data to inform clinical decisionmaking (Kvasz et al. 2000, Lazarou et al. 1998). When considering the potential for interaction in a clinical setting, Callahan and Rabito (1990) suggest that special attention be given to extrapolating experimental data to the clinical situation, as the observed effects may depend on the amount of drug present.

Because much of the evidence is in the form of case studies (e.g. anecdotal) many suspected interactions may eventually be proven false; be they due to chance or noncausal associations (i.e. confounding). Here, we do not make causal assessments of individual case reports, but instead provide an overview of what has been reported in the medical literature.

Drug-radiopharmaceutical interactions may arise as a result of a variety of factors including the pharmacological action of the drug, physiochemical interactions between drugs and radiotracers, and competition for binding sites for example. Diseases induced by drugs, which may be potentiated by a radiopharmaceutical, would also be considered an adverse event (Hesslewood and Leung 1994).

While we focus on drug-radiopharmaceutical interactions in situ, it is also important to consider that handling and processing may also cause or increase the risk of adverse reactions. For example, contamination during the dispensing or administration may alter the sub- 
sequent biodistribution o the radiopharmaceuticals. The most well known are interactions with the antiseptics povidone iodine and chlorhexidine. Iodine-based antisepsis, in presence of labeled compounds as ${ }^{99} \mathrm{Tc}$, may release free pertechnetate (Fisher et al. 1977). Similarly, chlorhexidine gluconate can react to form technetiumgluconate complex, which is taken up by the kidney (Sampson and Hesslewood 1989). Although less commonly reported, radiopharmaceuticals may also interact with the syringe or catheter components (Slater et al. 1983, Millar et al. 1983).

Lifestyle factors, such as cigarette smoking, alcohol intake, and dietary habits (e.g. high dose of vitamins) also have the potential of interacting with radiopharmaceuticals.

A study carried out in Brazil showed that the concentration of ${ }^{99 m}$ Tc-RBC (Technetium-99-m labeling of erythrocytes) and ${ }^{99 m}$ Tc-PP (Technetium-99-m labeling of plasma protein) in blood can be decreased among cigarette smokers, even those whose habit is classified as light or moderate. The lack of a dose-response suggests that the effect may be ascribed to the generation of ROS (reactive oxygen species). Regardless of the mechanism, this can interfere with the performance of nuclear imaging procedures that use labeled Technetium (Vidal et al. 1998).

\section{REVIEW}

Radioisotopes are used in nuclear medicine for diagnostic and therapeutic purposes. Radiopharmaceuticals may be used in oncology for the initial staging, to assess response to treatment, residual disease, recurrent diagnosis and restaging, but specifically among the different types of tumor. Another field of study is that of large vessel vasculitis, granulomatous diseases and dementias (Ruiz-Laiglesia et al. 2008).

\section{ORGANS-ADVERSE REACTION}

ADR's (Adverse Drug Reactions) are typically thought of as serious, isolated clinical events that may be related to patient characteristics, environment, and the particular exposure. However, an ADR is not always a readily detectable clinical event, but instead can be clinically silent (Jones 1982). For example, subclinical elevations of hepatic transaminases and blood urea nitrogen, or de- crease in sperm count may go unrecognized, or may be detected only by chance. The possibility of clinically silent adverse events with radiopharmaceuticals, and particularly radiopharmaceutical-drug interactions, should be considered. Here we review the literature on reports of both overt and clinically silent adverse events associated with radiopharmaceutical-drug interactions by organ system.

\section{ADRENAL}

Interactions with adrenal cortex and adrenal medulla agents have been reported. In view of the difference in physiology of the two regions of the gland, it is not surprising that these interactions occur with different groups of drugs (Solanki et al. 1992). Such interactions can have varying effects on the resulting image, depending on whether the drug increases or decreases the uptake of the radiopharmaceutical. In many cases the effect may be predicted based on the known pharmacological actions of the interacting drug (Hesslewood and Leung 1994).

Spironolactone affects the uptake of ${ }^{131}$ Iodometilnor-cholesterol by the adrenal cortex. It has been reported to both increase uptake (Hladik et al. 1987, Fischer et al. 1983, Khafagi et al. 1991) as well as decrease uptake (Hladik et al. 1987, Gross et al. 1981). An increase in ${ }^{131}$ Iodomethyl-nor-cholesterol uptake by the adrenal gland is a result of the steroid synthesis from plasma. As such, it may result in false positive diagnosis of adrenocortical adenomas, adrenal incidentalomas and pheochromocytoma (Fischer et al. 1972, Hladik et al. 1987, Bardet et al. 1996, Mansmann et al. 2004). Spironolactone can also decrease aldosterone synthesis by decreasing the uptake of radiolabeled cholesterol by the adrenal cortex. This also has the potential to interfere in tumor diagnosis (Hesslewood and Leung 1994, Fischer et al. 1972).

Oral contraceptives have been found to increase the binding of adrenal cortex imaging agent ${ }^{131}$ Iodomethylnor-cholesterol by increasing plasma renin activity. This results in adrenocortical stimulation; increased cortisol secretion and hyperplasia. They may cause false positives or just uninterpretable results complicating the interpretation of adrenal scintigrams (Gross et al. 1981, Swanson et al. 1990) potentially requiring retesting and exposing the patient to unnecessary radiation. 
Yurekli et al. (2005) investigated the cytoprotective potential of amifostine against doxorubicin-induced cardiotoxicity. Using the radiopharmaceutical ${ }^{99 \mathrm{~m}} \mathrm{Tc}-$ MIBI, they demonstrated that amifostine (amifostina Ethyol ${ }^{\circledR}$ ) administration, 30 minutes before doxorubicin injection, resulted in a significant decrease in absorption of radioactivity by the adrenal, compared with doxorubicin alone. These results showed that amifostine may significantly attenuate doxorubicin-induced cardiotoxicity. They also show the potential for amifostine to impact radiopharmaceutical imaging of the adrenal gland.

\section{GASTROINTESTINAL}

The uptake and secretion of ${ }^{99 \mathrm{~m}} \mathrm{Tc}$-pertechnetate by the gastric mucosa may be affected by drugs, thereby interfering with the imaging of Meckel's diverticulum (Hesslewood and Leung 1994). Moreno et al. (2007b) showed that extracts of Ginkgo biloba decreased the uptake of ${ }^{99 \mathrm{~m}}$-Tc-sodium-pertechnetate in the duodenum, kidney and liver. The alteration of uptake was significant in the duodenum. Radiobiocomplexes as sodium pertechnetate $\left(\mathrm{Na}^{99 \mathrm{~m}} \mathrm{Tc} 0^{4}\right)$ are tracers widely utilized for scintigraphic studies mainly for thyroid, brain and stomach. $\mathrm{Na}^{99 \mathrm{~m}} \mathrm{Tc} 0^{4}$ has also been used to label blood constituents (Early and Sodee 1996). Therefore, alterations in the uptake by the duodenum may be crucial for the hepatobiliary scintigrahy in the diagnosis of duodenogastric reflux and dysfunction of the Oddi's sphincter in post-cholecystectomy syndrome for example (Pope and Bratke 1981).

\section{BRAIN}

The major risk of drug-radiopharmaceutical interactions occurs with pharmaceuticals that can alter the permeability of the blood-brain barrier. Verhoeff (1991) states that some pharmaceuticals may influence the receptor-bound neurotransmitters. This may cause false results and subsequently, misdiagnosis. Also, cytotoxic drugs such as cyclophosphamide, vincristine, bleomycin and cisplatin are reported to affect the pharmacokinetic response of radiopharmaceuticals, such as the tumor-seeking radiopharmaceutical ${ }^{67} \mathrm{Ga}$-citrate. This radiopharmaceutical localizes in some neoplasms as well as other sites, including the liver and regions of infection or inflammation. That may result in a very high uptake of tracer in blood with little or no uptake by the tumor (Lentle and Scott 1979, Sampson 1993). Another study made by Van Leeuwen-Stok et al. (1998) demonstrated that ${ }^{67}$ Gallium used with other cytostatic drugs except for methotrexate might be used together or sequentially in therapy because it potentiated the cytostatic effect.

One of the most well documented drug/radiopharmaceutical interactions is the suppression of ${ }^{67} \mathrm{Ga}$-citrate uptake in cerebral tumors among patients taking cortisone preparations (Sampson 1993, Waxman et al. 1997). This is thought to result from a decrease in extracellular sodium and fluid volume. As the tracer is often associated with the oedematous fluid, it creates the appearance of a tumor decreased in size in the scintigraph. This effect may be so pronounced that it suppresses all uptake of tracer into the tumor, causing the tumor to be missed completely, possibly resulting in misdiagnosis. Similarly, among patients treated with deferoxamine, a chelating agent used to treat iron overload and aluminum toxicity, there was diffuse tracer activity and poor tissue localization with complete absence of normal uptake by ${ }^{67} \mathrm{Ga}$-citrate. This occurs because deferoxamine forms a complex with ${ }^{67} \mathrm{Ga}$ that is stronger than that of ${ }^{67} \mathrm{Ga}$ with tranferrin, thus interfering with ${ }^{67} \mathrm{Ga}$-transferin binding and subsequent cellular uptake. (Sampson 1993, Hesslewood and Leung 1994, Waxman et al. 1997).

\section{BONE}

The constant remodeling of bone guides the choice of tracers, to identify anomalies in the bone structure or pathologies related to the remodeling process. Therefore, pharmaceuticals that have an impact in any of these processes have the potential to interact with radioimaging of bone. Due to the complex process involving the uptake of phosphate by the bone, a number of pharmaceuticals may modify the biodistribution of the ${ }^{99 \mathrm{~m}}$ Tc-labeled-diphosphate. For example, etidronate and pamidronate, which are diphosphonates used in the treatment of Paget's disease, compete with MDP $\left({ }^{99 \mathrm{~m}} \mathrm{Tc}\right.$-methylene-diphosphate) due to structural similarity (Sandler et al. 1991, Hommeyer et al. 1992). Such competition may result in false negative images (faulty diagnosis).

Also used in bone imaging, the biodistribution of ${ }^{99 \mathrm{~m}}$ Tc-PYP (sodium pyrophosphate/sodium trimeta- 
phosphate-tin) may be altered by concomitant use of sodium diatrizoate. Use of diatrizoate with ${ }^{99 \mathrm{~m}} \mathrm{Tc}-\mathrm{PYP}$ has been shown to cause significant renal and liver uptake of the radiopharmaceutical, interfering with the performance of nuclear imaging procedures (Crawford and Gumeran 1978). In the worst case, this can result in a faulty diagnosis.

There have been numerous reports of interactions between the intramuscular iron dextran and ${ }^{99 \mathrm{~m}} \mathrm{Tc}-\mathrm{MDP}$. Taken together, iron dextran modifies the biodistribution of ${ }^{99 \mathrm{~m}} \mathrm{Tc}-\mathrm{MDP}$, such that the tracer concentrates at the site of injection, instead of diffusing throughout the skeleton (Forauer et al. 1994, Eisenberg et al. 1990). It is thought that localized complexing occurs between reduced technetium and ferric hydroxide, as the latter is released from the iron dextran complex. This may impact the skeletal scintigraphy of tumors (Mazzole et al. 1976, Sampson 1993), potentially preventing or delaying their diagnosis.

\section{HEART}

The most commonly used radiopharmaceutical for visualizing the heart is labeled thallous $\left({ }^{201} \mathrm{Tl}\right)$. The use of thallous with $\beta$-blockers can result in a temporary decrease in the severity of perfusion defects (Van Der Wall et al. 1983) Other studies (reports) have suggested that there is actually a net increase in the assessed severity among patients with minor coronary disease upon angiography (Hesslewood and Leung 1994). While $\beta$ blockers may interfere in the imaging results, suspending use prior to imaging is not recommended, as it may increase the risk of myocardial ischaemia (Bridges et al. 1992) Doxorubicin also has the potential to impact cardiac imaging. In an experimental study, ${ }^{201} \mathrm{Tl}$ uptake was significantly higher in the hearts of doxorubicintreated rats compared to the control rats, indicating a slow wash-out of ${ }^{201} \mathrm{Tl}$ from the myocardium (Miyagawa et al. 1991, Yurekli et al. 2005).

According to Narahara et al. (1989), this apparent decrease in severity of perfusion defects upon radioimaging is dependent on the dose of the radiopharmaceutical (201-Tl) that goes to heart. When this occurs, the quality of the imaging is insufficient for accurate analysis and in consequence, is of limited value for diagnosis.
The radiopharmaceutical ${ }^{99 \mathrm{~m}} \mathrm{Tc}$-pyrophosphate is widely used to detect myocardial infarctions. Diminished cardiac activity and increased renal activity has been observed with the use of heparinised catheters for in vivo red cell labeling with ${ }^{99 \mathrm{~m}} \mathrm{Tc}$-pyrophosphate. This results in increased renal elimination of the radiopharmaceuticals, which can adversely effect visualization of the organ (Sampson 1990, Lentle and Scott 1979, Chacko et al. 1997, Hegge et al. 1978). Another labeled tracer, ${ }^{99 \mathrm{~m}}$ Tc-DTPA is also used in cardiac imaging. Mitomycin $\mathrm{C}$ has been shown to decrease the uptake of ${ }^{99 \mathrm{~m}} \mathrm{Tc}$-DTPA by cardiac muscle, potentially interfering in the performance of the diagnostic procedure (Gomes et al. 2001).

Antimyosin labeled with ${ }^{111}$ Indium is specific for myocyte necrosis and is used in the detection of infarct, myocarditis and cardiac rejection. Chemotherapeutic drugs, notably doxorubicin, have been shown to cause increased myocardial uptake of the radiopharmaceutical (Estorch et al. 1990). Reuland et al. (1992) determined that doxorubicin decreased the uptake of ${ }^{111}$ Indium antimyosin by the kidney. One randomized trial investigated the value of cardiac radioimmunoscintigraphy with ${ }^{111}$ Indium antimyosin monoclonal antibodies in the early detection of cardiac damage. The results of these trials demonstrate that DEX (dexrazoxane) is able to ameliorate doxorubicin- and epirubicin-induced cardiotoxicity, even when high single drug doses are used (Lopez and Vici 1998). Radioimmunoscintigraphy was very sensitive in detecting anthracycline cardiac damage, but its specificity is low and it cannot be considered a primary test for guiding anthracycline treatment. This suggests that ${ }^{111}$ Indium-antimyosin could potentially be used to monitor the degree of cardiotoxicity produced by doxorubicin (Carrio et al. 1993).

The extract of Uncaria tomentosa (cat's claw) is used as complementary treatment for AIDS and cancer (Sheng et al. 2000, Williams 2001). It can reduce the uptake of radiobiocomplex sodium pertechnetate in heart (Moreno et al. 2007a). Again, this may decrease the visualization of the organ, requiring a repeat procedure. There is also the potential for misdiagnosis.

Recent studies showed that cardiac ${ }^{18}$ F-FDG uptake was significantly lower among diabetics and also among patients taking either bezafibrate or levothyroxine. Cardiac ${ }^{18} \mathrm{~F}$-FDG uptake was significantly higher in men, 
patients less than 30 years old, patients with heart failure, and those receiving benzodiazepines. Potentially, pharmaceutical manipulation of ${ }^{18} \mathrm{~F}$-FDG may provide an opportunity to optimize PET/CT imaging (Israel et al. 2007).

\section{HEPATOBILIARY}

The radiopharmaceutical, ${ }^{99 \mathrm{~m}} \mathrm{Tc}$-iminodiacetic $\left({ }^{99 \mathrm{~m}} \mathrm{Tc}-\right.$ IDA) is used in the diagnosis of cholecystitis, focal nodular hyperplasia, degree of functional disorder in acute hepatic disease and to evaluate the severity of diffuse hepatic disease among others functions (Alobaidi et al. 2004, Broglia et al. 1998, Aburano et al. 1993). As an acid, the ${ }^{99 \mathrm{~m}}$ Tc-iminodiacetic acid is removed from blood by hepatocytes. Acids are subsequently transported to the gallbladder, where they are discharged through the cystic duct into the common bile duct and then into the intestines (Feezer 1982). A variety of drugs have been reported to interfere with hepatobiliary imaging by affecting the movement of the radiopharmaceuticals through the hepatobiliary system (Hesslewood and Leung 1994). These include isoniazid and pyrazinamide, which are anti tubercular drugs that have been shown to elevate liver enzymes and consequently hepatobiliary system is the most common system affected (Pv et al. 2008).

Technetium gluceptate is a radiopharmaceutical drug widely used to visualize renal structures, particularly kidney parenchyma. Concurrent administration with penicilamine, penicillin $\mathrm{G}$ potassium, penicillin $\mathrm{V}$ potassium, acetaminophen or trimetroprim-sulfamethoxazole, may substantially alter the biodistribution of ${ }^{99 m}$ Technetium gluceptate. If the impact is large enough, abnormal gallbladder images may result. Affected images can mimic abnormal kidney localization on posterior views (Hinkle et al. 1982), resulting in misdiagnosis.

\section{KIDNEY}

Appropriate imaging in uro-oncology is a crucial component at primary diagnosis, follow up and recurrence to achieve accurate assessment of the disease and determine the most effective treatment. The recent published literature on positron emission tomography and positron emission tomography/computerized tomography in urooncology has shown a great number of radiopharmaceuticals that may be used for urological malignancies e.g. for prostate cancer ${ }^{18} \mathrm{~F}$-fluorodeoxyglucose, ${ }^{11} \mathrm{C}$ choline, ${ }^{18} \mathrm{~F}$-fluorocholine, ${ }^{11} \mathrm{C}$-acetate and ${ }^{18} \mathrm{~F}$-fluoride (Bouchelouche and Oehr 2008).

As most drugs are metabolized in the kidney, there is great potential for drug-radiopharmaceutical interactions. Many drugs alter kidney function in a dosedependent manner. In patients with unilateral renal artery stenosis, angiotensin converting enzyme inhibitors (ACE-Inhibitors) decrease glomerular filtration in the affected kidney by the interruption of autoregulatory mechanism causing problems in the distribution of the radiopharmaceuticals (Hesslewood and Leung 1994). A case report showed that calcium antagonists can cause false-positive captopril renograms. These medications should be stopped before captopril renography, and physicians should be aware of this possible drug interaction if bilateral symmetrical renal function deterioration is seen in a patient's captopril renogram (ClaveauTremblay et al. 1998).

The authors Latham et al. (1992), state that the use of drugs like dipyridamole increases or, depending on the concentration may decrease, the excretion of ${ }^{99 \mathrm{~m}} \mathrm{Tc}$ DTPA ( ${ }^{99 \mathrm{~m}} \mathrm{Tc}$-diethylenetriamine penta-acetic acid) by the kidney. Diuretics as furosemide may improve renal function so that misleading good renograms and flow curves are obtained when using the renal imaging agent ${ }^{9 m}$ Tc DTPA (Sampson 1993).

\section{INFECTION/INFLAMATION}

Labeled leukocytes are used to the diagnosis of lung disease, rheumatoid arthritis, detection of inflammation and a variety of other diagnostic modalities (Van Hemert et al. 2007) A very common problem related to labeled leukocytes in infection and inflammation diagnosis are false-negative results. This drug-interaction has been attributed to the use of antibiotics and corticosteroids. This occurs because of the reduction in the chemoattractant stimuli for the labeled leukocytes (Hladik et al. 1987). However, Chung et al. (1991) and Datz and Thorne (1986), state that the use of antibiotics does not affect the results.

An important case of false-positive reaction is related to the hip arthroplasty. A retrospective and prospective study conducted by Zhuang et al. (2002) with 710 patients and 9 patients respectively, concluded that, 
following hip arthroplasty, non-specifically increased FDG uptake around the head or neck of the prosthesis persists for many years, even in patients without any complications. Therefore, to minimize the number of false-positive results with PET studies, caution should be exercised when interpreting FDG uptake around the head or neck portion of prostheses.

\section{LIVER/SPLEEN}

The imaging agent ${ }^{99 \mathrm{~m}} \mathrm{Tc}$-hepato-iminidiacetic acid $\left({ }^{99 \mathrm{~m}} \mathrm{Tc}-\mathrm{HIDA}\right)$ used to pancreas scintigraphy. Drugs that alter the transport in the reticuloendothelial may decrease the uptake of radiopharmaceuticals, such as ${ }^{99 \mathrm{~m}} \mathrm{Tc}-\mathrm{HIDA}$, in the liver and spleen (Hesslewood and Leung 1994). As such, they can lead to misdiagnosis. The impact can be quite large. A case report has been published on the complete absence of ${ }^{99 \mathrm{~m}} \mathrm{Tc}-\mathrm{HIDA}$ upon imaging, in a patient taking nicotinic acid (Sampson 1993).

Aluminum is present in a number of medications, most commonly in antacids. There is an increasing number of case reports of interactions between aluminum and radiopharmaceuticals. Aluminum-containing drugs can cause flocculation of colloidal particles of sulfur (used in liver scanning), such that the particles get trapped in the microvasculature of the lungs decreasing the uptake of the radiopharmaceutical (Bobinet et al. 1974). Labetalol, used for the treatment of pheocromacytoma, reduces the uptake of ${ }^{131}$ Iodine- metaiodobenzylguanidine $\left({ }^{131}\right.$ Iodine- MIBG) in liver and spleen (Khafagi et al. 1989). Gomes et al. (2001) noted that mitomycin C increased the uptake of ${ }^{99 \mathrm{~m}} \mathrm{Tc}-\mathrm{DTPA}$ by the spleen and liver and also increased the uptake of ${ }^{99 \mathrm{~m}} \mathrm{Tc}-\mathrm{GHA}$ by the liver causing misdiagnosis and or a false positive result.

\section{THYROID}

The most commonly used thyroid imaging radiopharmaceuticals are ${ }^{131}$ iodide and ${ }^{123}$ iodide. Thus, drugs or pharmaceuticals with iodide in their formulation, may affect directly in the absorption of these radiopharmaceuticals through competition for receptor sites. Somatostatin also interferes with thyroid imaging through the same mechanism, absorption by receptor sites (Hesslewood and Leung 1994).

Competing anions, such as perchlorate and pertech- netate ions, act as competitive inhibitors of the iodine transport mechanism. This can lead to decreased uptake of ${ }^{131}$ I sodium iodide. Inorganic iodine-containing medications such as Lugol's iodine as well as some vitamin/mineral supplements, are thought to release iodine thereby decreasing the specific activity of iodide in the body pool. This would also decrease uptake of radioiodine into the thyroid gland (Sternthal et al. 1980, Laurie et al. 1992). Similarly, use of mitomycin C decreased the uptake of ${ }^{99 \mathrm{~m}} \mathrm{Tc}-\mathrm{GHA}$ by the thyroid (Gomes et al. 2001).

Radioiodinated meta-iodobenzylguanidine (MIBG) plays a role in both the diagnosis and treatment of a wide range of tumors; phaeochromacytoma, neuroblastoma, carcinoid tumors and medullary carcinoma of the thyroid (Sisson et al. 1981, Horne et al. 1984, Fischer et al. 1983, Kimming et al. 1984, Bomanji et al. 1987, Sone et al. 1985). Over 20 medicines have the potential to interfere with the biodistribution of MIBG, sometimes many hours after they have been taken. Among those, the most commonly encountered interacting agents are chlorpromazine; clomipramine, diltiazem, dopamine, fluphenazine, labetalol, mazindol, nifedipine, promethazine and salbutamol. This interference is enough to impact the efficacy of MIBG as a diagnostic and therapeutic modality because of the extremely low quantities of radiolabeled MIBG that are present in the radiopharmaceutical. Therefore, it is recommended that treatment with any potentially interacting drug be stopped one week prior to imaging with MIBG (Solanki et al. 1992).

Thyrostatic drugs have modified the kinetics of radioiodine in the thyroid and through this mechanism may also have a radioprotective effect. Pre-treatment with thyrostatic medication lowers the effective half-life and uptake of radioiodine. However, this interaction also reduces the effective dose of the thyrostatic medication in the thyroid. Discontinuation of such medications shortly before radioiodine administration can increase the absorbed energy dose in the thyroid. These drug-radiopharmaceutical interactions may also have a clinical role in lowering the effective dose of radioiodine while achieving an equally effective target dose in the thyroid (Moka et al. 2002). While it does not impact imaging, administration of non-radioactive iodine within a few days after radioiodine administration 
can increase the effective half-life of radioiodine in the thyroid. Therefore, its use should be suspended until few days after imaging with radioiodine, to facilitate clearance of the radioisotope.

\section{NONSPECIFIC INTERACTIONS}

There are a number of drugs which interact across a range of radiopharmaceuticals including those used for whole body (e.g. non-organ specific) imaging. Also, drug-induced disease states can alter the biodistribution of radiopharmaceuticals (Sampson 1990). For example, cytotoxic drugs such as cyclophosphamide, vincristine, and cisplatin are reported to affect the pharmacokinetic response of radiopharmaceuticals, particularly the tumor-seeking radiopharmaceutical ${ }^{67} \mathrm{Ga}$.

Antimetabolites, such as cytarabine and methotrexate, have similar effects (Sampson 1993). Analogues of somatostatin (nonlabeled) are used therapeutically in the Carcinoid Syndrome. There have been reports of falsenegative results when patients using somatostain were imaged with ${ }^{111}$ In-pentetreotide due to a competition for the receptors sites (Dorr et al. 1993, Hesselwood and Leung 1994).

\section{RESUMO}

Os radiofármacos desempenham função crítica na medicina moderna, primariamente para fins diagnósticos, mas também no monitoramento da progressão de doenças assim como na avaliação de respostas ao tratamento. $\mathrm{O}$ uso da tecnologia por imagem tem crescido e conseqüentemente as prescrições de medicamentos (radiofármacos em especial) com esse propósito. Este fato, aumenta o risco de interações entre medicamentos e radiofármacos. Interações que podem ter um impacto na imagem, podem resultar em falso negativo e assim ter sérias conseqüências para o paciente. Já drogas que aceleram o metabolismo podem ter resultado positivo pois podem aumentar a taxa de eliminação do radiofármaco (clearance acelerado). Contudo, podem ainda ter resultados negativos, se a interação resultar em necessidade de repetição do exame. Em alguns casos, por exemplo em imagem cardíaca, entre pacientes sob o uso de doxarubicina, essas interações podem ter efeito terapêutico. A incidência de efeitos adversos envolvendo radiofármacos é desconhecida, além de não ser oficialmente reconhecida, nem notificada, principalmente no Brasil. Nesse estudo foram compilados da literatura médica, usando a metodologia da revisão sistemática, estabelecida pela Cochrane Collaboration, estudos e relatos de interações medicamentosas com radiofármacos. O objetivo é prover uma referência (sumário) de interações medicametosas com radiofármacos que possa auxiliar a medicina nuclear na sua rotina diária. Contudo, esforços devem ser feitos na tentativa de instituir a notificação de efeitos adversos com radiofármacos, e assim prevenir esse tipo de interação.

Palavras-chave: radiofármacos, radiofarmácia, interação medicamentosa, revisão sistemática.

\section{REFERENCES}

Aburano T, Yokoyama K, Shuke N, Takayama T, Michigishi T, TONAMi N, Hisada K, UnOURA M AND KoBAYASHI K. 1993. 99mTc colloid and 99m Tc IDA imagings in diffuse hepatic diseases. J Clin Gastroenterol 17: 321-326.

Alobaidi M, Gupta R, Jafri S And Fink-Bennet D. 2004. Current trends in imaging evaluation of acute cholecystitis. Emerg Radiol 10: 256-258.

BARDET S ET AL. 1996. 131-6- $\beta$-Iodomethylnorcholesterol scintigraphy: an assessment of its role in the investigation of adrenocortical incidentalomas. Clin Endocrinol 44: 587-596.

Bobinet EB, SEverin M And Zurbriggen MT. 1974. Lung uptake of tc-99m sulphur colloid in patients exhibiting presence of aluminium in plasma. J Nucl Med 15: 1120-1122.

Bomanji J, LEVISON DA, ZUZARTE J AND BRITTON KE. 1987. Imaging of carcinoid tumors with 123i-mibg. J Nucl Med 28: 1907-1910.

Bouchelouche K AND Oehr P. 2008 Positron emission tomography and positron emission tomography/computerized tomography of urological malignancies: an update review. Urol 179: 34-35.

Bridges AB, Kennedy N, McNeIll GP, COOK B AND PRINGLE TH. 1992. The effect of atenolol on dipyridamole 201-T1 myocardial perfusion tomography in patients with coronary artery disease. Nucl Med Commun 13: 41-46.

Broglia L, Bezzi M, Massa R, Tortora A, Rossi M, Prosperi D, Maccioni F And Rossi P. 1998. Computerized tomography, magnetic resonance and nuclear medicine in the non-invasive diagnosis of focal nodular hyperplasia of the liver. Radiol Med (Torino) 96: 218225.

Budnitz DS, Pollock DA, Weindenbach KN, MenDelshon AB, Schroeder TJ And Annest JL. 2006. National surveillance of emergency department visits for outpatient adverse drug events. JAMA 296: 1858-1866. 
Callahan RJ And Rabito CA. 1990. Radiolabeling of erythrocytes with technetium- $99 \mathrm{~m}$ : role of band-3 protein in the transport of pertchnetate across the cell membrane. J Nucl Med 31: 2004-2010.

CARrio I, Lopez-Pousa J AND MARInez-Duncker D. 1993. Comparison of cardiotoxicity by In-111 antymioyosin studies: bolus administration versus continuos infusion of doxorubicin. Eur J Nucl Med 20: 833-834.

Chacko AK, Gordon DH, Bennet JM, O'Mara RE AND WILSON GA. 1997. Myocardial imaging with Tc$99 \mathrm{~m}$ pyrophosphate in patients on adriamycin treatment for neoplasia. J Nucl Med 18: 680-683.

Chung CJ, Hicklin OA, Payan JM and Gordon L. 1991. Indium-111-labelled leukocyte scan in detection of synthetic vascular graft infection: the effect of antibiotic treament. J Nucl Med 32: 13-15.

Claveau-Tremblay R, Turpin S, De Braekeleer M, BRASSARD A AND LEBLOND R. 1998. False-positive captopril renography in patients taking calcium antagonists. J Nucl Med 39: 1621-1626.

Cordova MA, Rhodes BA, Atkins HL, Glenn HJ, Hoogland DR AND Solomon AC. 1982. Adverse reactions to radiopharmaceuticals. J Nucl Med 23: 550551.

CraWford JA AND Gumeran LW. 1978. Alteration of body distribution of $99 \mathrm{~m}$ Tc-pyrophosphate by radiographic contrast material. Clin Nucl Med 3: 305-307.

DATZ FL AND THORNE DA. 1986. Effect of antobiotic therapy on the sensitivity of indium-111-labelled leukocyte scans. J Nucl Med 27: 1849-1853.

Dorr U, RATh U, SAUter-Bihl M-L, GuZMan G, BACH D, AdRIAN HJ AND BIHL H. 1993. Improved visualization of carcinoid liver metastases by indium-111 pentetreotide scintigraphy following treatment with cold somatostatin analogue. Eur J Nucl Med 20: 431-433.

EARLY PJ AND SodeE DB. 1996. Principles and Practice of Nuclear Medicine, New York: Mosby Year Book, p. 100.

Eisenberg B, Meholic AJ, Arrington ER, Elliott TM, Wiest PW AND OlANDER RL. 1990. Iron dextran: bone imaging patterns of aborption - a case report. Am J Physiol Imaging 5: 116-118.

ESTORCH M, CARrio I, BERNA L, MARTINEZ-DUNCKER C, Alonso C, Gérman JP And OJeda B. 1990. Indium-111 antimyosin scintigraphy after doxorubicin theraphy in patientes with advanced breast cancer. J Nucl Med 31: 1965-1969.

FEEZER EA. 1982. Hepatobiliary imaging: general considerations. The view box, july issue, Dep. Nucl. Med, Wesley Medical Centre, Kansas, p. 154.
Fischer M, Vetter W AND Winter B. 1972. Adrenal scintigraphy in primary aldosteronism. Spironolactona as a cause of incorrect classification between adenona and hyperplasia. Eur J Nucl Med 7: 222-224.

Fischer M, Winterberg B AND Muller-Rensing R. 1983. Radioisotopic therapy of pheochromocytoma. Nucl Compact 14: 172-176.

Fisher SM, Brown RG AND GREYSON ND. 1977. Unbinding of Tc-99m by iodinated antiseptics. J Nucl Med 18: $1139-1140$.

Forauer AR, Grossman SJ And Joyce JM. 1994. Altered biodistribution of Tc99m HMDP on bone scintigraphy from recent intravenous iron therapy. Clin Nucl Med 19: $817-818$.

Gomes ML, Mattos DMM, Souza-Freitas R, BezerRAL RJ AND BERNARDO-FILHO M. 2001. Study of the toxicological effect of mitomycin c in mice: alteration on the biodistribution of radiopharmaceuticals used for renal evaluations. Hum Exp Toxicol 20: 193-197.

Gross MD, VALK TW, SAWANSON DP, Thrall JH, GREKIN RJ AND BEIREWALTES WH. 1981. The role of pharmacologic manipulation in adrenal cortical scintigraphy. Semin Nucl Med 11: 128-148.

Hegge FN, Hamilton GW And LARSOn SM. 1978. Cardiac chamber imaging: a comparison of red blood cells labelled with tc-99m in vitro and in vivo. J Nucl Med 19: 129-134.

Hesslewood S AND LeUnG E. 1994. Drug interaction with radiopharmaceuticals. Eur J Nucl Med 21: 348-356.

Hesslewood S And KeEling DH. 1997. Frequency of adverse reactions to radiopharmaceuticals in Europe. Eur J Nucl Med 24: 1179-1182.

Hinkle GH, Basmandjian GP, Peek C, BaKer KK AND ICE RD. 1982. Effects of concurrent drug therapy on technetium tc-99m gluceptate biodistribution. Am J Hosp Pharm 39: 1930-1933.

Hladik WB, Ponto JA, Lentle BC And Laven DL. 1987. Iatrogenic alterations in the biodistribution of radiotracers as a result of drug therapy: reported instances. In: Hladik WB, SAha GB And Study KT (Eds), Essentials of Nuclear Medicine Sciences. Sydney: Williams and Wilkins, p. 189-219.

Hommeyer SH, VARNEY DM AND EARY JF. 1992. Skeletal nonvisualization in a bone scan secondary to intravenous etidronate therapy. J Nucl Med 33: 748-750.

Horne T, HAWKings LA AND BRITTON KE. 1984. Imaging of phaeochromocytoma and adrenal medulla with 123 I-metaiodobenzylguanidine. Nucl Med Commun 5: 763768. 
ISRAEL O, WeILER-SAGIE M, Rispler S, BAR-SHALOM R, Frenkel A, Keidar Z, Bar-Shalev A AND STRAUSS HW. 2007. PET/CT quantification of the effect of patient-related factors on cardiac 18-F-FDG uptake. J Nucl Med 48: 234-239.

JONES JK. 1982. Adverse drug reactions in the community health setting: approaches to recognizing, counseling, and reporting. Fam Community Health 5: 58-67.

KeELING DH. 1994. Adverse reactions and untoward events associated with the use of radiopharmaceuticals. In: SAMPSON CB (Ed), Textbook of radiopharmacy theory and practice. Yverdon: Gordon and Breanch Science Publishers, p. 285-295.

Khafagi F, Shapiro B, Lorraine M, Mallette S And SISSON JC. 1989. Labetolol reduces iodine-131-mibg uptake by pheochromacytom and normal tissues. J Nucl Med 30: 481-489.

Khafagi FA, Shapiro B And Gross MD. 1991. The adrenal gland apud Maisey MN, Britton KE and Gilday DL. Clinical nuclear medicine. London: Chapman and Hall, p. 271-291.

Kimming B, Brandeis We, Eisenhut M, Bubeck B, HERMANN HJ AND WINKEL K. 1984. Scintigraphy of a neuroblastomas with $131 \mathrm{i}$ mibg. J Nucl Med 25: 773775 .

Kusabe K, Okamura T, Kasagi K, Komatani A, Sato Y, Matsuda H and Maruno H. 2006. Subcommittee for Safety Issues of Radiopharmaceuticals, Medical Science; and Pharmaceutical Committee, Japan Radioisotope Association. [The $27^{\text {th }}$ Report on Survey of the Adverse Reaction to Radiopharmaceuticals (the $30^{\text {th }}$ survey in 2004)] Kaku Igaku 43: 23-35.

Kvasz M, Allen E, Gordon MJ, Ro EY, Estok R, OLKIN I AND Ross SD. 2000. Adverse drug reactions in hospitalized patients: a critique of a meta-analysis. Med Gen Med 2: 1-13.

Latham tB Prato FS, Wisenberg G and Reese L. 1992. Effects of dipyrdamole infusion on human renal function observed using technetium-99m-dtpa. J Nucl Med 33: 355-358.

LAURIE AJ, LyON SG AND LASSER EC. 1992. Contrast material iodides: potential effects on radioactive iodine thyroid uptake. J Nucl Med 33: 237-238.

Lazarou J, Pomeranz BH And COREy PN. 1998. Incidence of adverse drug reactions in hospitalized patients a meta-analysis of prospective studies. JAMA 279: 12001204.

LENTLE BC AND SCOTT JR. 1979. Iatrogenic alterations in radionuclide biodistribuition. Semin Nucl Med 9: 131134.

LOPEZ M AND VICI P. 1998. European trials with dexrazoxane in amelioration of doxorubicin and epirubicin-induced cardiotoxicity. Semin Oncol 25: 55-60.

Mansmann G, Lau J, Balk E, Rothberg M, Miyachi Y AND BORNSTEIN SR. 2004. The clinically inapparent adrenal mass: update in diagnosis and management. Endocr Rev 25: 309-340.

Mazzole AC, Barker MM and Belliveal RE. 1976. Accumulation of tc-99m-diphosphonate at sites of intramuscular iron therapy. J Nucl Med Tech 4: 133-135.

Millar AM, Wathem CJ AND Muir AL. 1983. Failure in labelling of red cells with tc-99: interaction between intravenous cannulae and stannous pyrophosphate. Eur J Nucl Med 8: 502-504.

Miyagawa M, Tanada S and Hamamoto K. 1991. Scintigraphic evaluation of myocardial uptake of thallium 201 and technetium $99 \mathrm{~m}$ pyrophosphate utilizing a rat model of chronic doxorubicin cardiotoxicity. Eur J Nucl Med 18: 332-338.

Moka D, Dietlein M, Schicha H. 2002. Radioiodine therapy and thyrostatic drugs and iodine. Eur J Nucl Med Mol Imaging 29: 486-491.

MORENO SRF ET AL. 2007a. Effect of oral ingestion of an extract of the herb uncaria tomentosa on the biodistribution of sodium pertechnetate in rats. Braz J Med Biol Res 40: $77-80$.

Moreno SRF, Carvalho JJ, Nascimento AL, Pereira M, Rocha EK, Olej B, Caldas lQA AND BERnARdo-FilHo M. 2007b. Experimental model to assess possible medicinal herb interaction with a radiocomplex: Qualitative and quantitave analysis of kidney, liver and duodenum isolated from treated rats. Food Chem Toxicol 45: 19-23.

NARAHARA KA, Thompson CJ, HAZEN JF, BRIZENDine M AND MenA I. 1989. The effect of beta-blockade on single emission computed tomographic (SPECT) thallium-201 images in patients with coronary disease. Am Heart J 117: 1030-1035.

Pope R AND BRATKE J. 1981. Two Tc-99mhda cases with delayded emptying into the duodenum. Monthly scan: College of Pharmacy New Mexico, Monthly Newsletter, May/June, sp.

PV K, Palaian S And PR S. 2008. Pattern of adverse drug reactions experienced by tuberculosis patients in a tertiary care teaching hospital in western Nepal. Pak J Pharm Sci 21: $51-56$. 
REUland P, RUCK P AND FEINE U. 1992. Correlation of chemotherapy-induced kdney disorder and antimyosin antibody uptake in kidneys. J Nucl Med 33: 309-311.

Ruiz-Laiglesia FJ, Oliveira-Gonzalez S AND TorRUBIA-PÉREZ CB. 2008. Diagnostic limitations of positron emission tomography. What are we seeking. Rev Clin Esp 208: 87-89.

SAMPSON CB. 1990. Drugs and chemicals wich affect the purity, biodistribuition and pharmacokinetics of radiopharmaceuticals. J Biopharm Sci 1: 381-400.

SAMPSON CB. 1993. Adverse reactions and drug interaction with radiopharmacuticals. Drug safety 8: 280-294.

SAMPSON CB AND Hesslewood SR. 1989. Altered biodistribution of radiopharmaceuticals as a result of pharmacological or chemical interaction. J Biopharm 5: 131-151.

SANDler ED, PARisi MT AND HattNer RS. 1991. Duration of etidronate effect demonstrated by serial bone scintigraphy. J Nucl Med 32: 1782-1784.

Sheng Y, Bryngelsson C And Pero RW. 2000. Enhaced DNA repair, immune function and reduced toxicity of c-med-100, a novel aqueous extract from Uncaria tomentosa. J Ethnopharmacol 69: 115-126.

SilbersteIn EB AND RYAN J. 1996. Prevalence of adverse reactions in nuclear medicine. J Nucl Med 37: 185-192.

Sisson JC, Frager MS, VALK TW, Gross MD, SWANSON DP, WiEland DM, TOBES MC, BeIERWALTES WH AND THOMPSON NW. 1981. Scintigraphic localization of pheochromocytoma. N Eng J Med 305: 12-17.

Slater DM, Anderson M AND Garvie NW. 1983. Syringe extractables, effects on radiopharmaceuticals. Lancet 17: 1431-1432.

Solanki KK, Bomanji J, Moyes J, MATher SJ, TRAINER PJ AND BRITTON KE. 1992. A pharmacological guide to medicines wich interfere with the biodistribution of radiolabelled meta-iodobenzyl-guanidine (MIBG). Nucl Med Commun 13: 513-521.

Sone T, Fukunaga M, Otsuka N, Morita R, MuraNAKa A, YANAGImoto S, TOMOMITSU T, NAKayama H AND HARADA T. 1985. Metasttatic medullary thyroid cancer, localisation with 131-i-mibg. J Nucl Med 26: 604-608.

Sternthal E, Lipworth L, Stanley B, Abreau C, FANG SL AND BRAVEMAN LE. 1980. Supression of thyroid radioiodine uptake by various doses of stable iodine. N Engl J Med 303: 1083-1088.
Swanson DP, Chilton HM AND Thrall JH. 1990. Pharmaceuticals in medical imaging. New York: Macmillan, p. $1-100$.

TEWson TJ AND Krohn KA. 1998. Pet radiopharmaceuticals: state-of-the-art and future prospects. Semin Nucl Med 28: 221-234.

VAn der Wall Ee, Westera G, van Eenige MJ, Scholtalbers S, Visser FC, Den Hollander W AND Roos JP. 1983. Influence of propranolol on uptake of radioiodinated heptadecanoic acid and thallium-201 in the dog heart. Eur J Nucl Med 8: 454-457.

Van Hemert FJ, Thurlings R, Dohmen SE, VoerMANS C, TAK PP, VAN ECK-SMIT BL AND BENNINK RJ. 2007. Labelling of autologous monocytes with $99 \mathrm{~m}-$ Tc-HMPAO at very high specific radioactivity. Nucl Med Biol 34: 933-938.

VAN LEEUWEN-STOK EA, JONKHOFF AR, VISSER-PlATiER AW, Dräger LM, Teule GJ, Huijgens PC AND SCHUURHuis GJ. 1998. Cell cycle dependency of 67 gallium uptake and cytotoxicity in human cell lines of hematological malignancies. Leukemia Lymphoma 31: 533-544.

VerhoefF NPLG. 1991. Pharmacological implications for neuroreceptor imaging. Eur J Nucl Med 18: 482-502.

Vidal MV, Gutfilen B, da Fonseca LM AND BerNARDO-FILHO M. 1998. Influence of tobacco on the labelling of red blood cells and plasma proteins with technetium-99m. J Exp Clin Cancer Res 17: 41-46.

Yurekli Y, UnAK P, ERTAY T, Biber Z, MEdine I AND TEKSOZ S. 2005. Radiopharmaceutical model using 99mtc-mibi to evaluate amisfostine protection against doxorubicin cardiotoxicity in rats. Ann Nucl Med 19: 197-200.

WAXMAn AS, Beldon JR, Richli WR, TANASESCU DE AND SIEMSEN JK. 1997. Steroid induced supression of gallium uptake tumours of the central nervous system. J Nucl Med 18: 617.

WiLliams JE. 2001. Review of antiviral and immunomodulating properties of plants of the Peruvian rainforest with a particular emphasis on uña de gato and sangre de grado. Altern Med Rev 6: 567-579.

Zhuang H, Chacko TK, Hickeson M, Stevenson K, Feng Q, Ponzo F, Garino JP And Alavi A. 2002. Persistent non-specific fdg uptake on pet imaging following hip arthroplasty. Eur J Nucl Med 29: 1328-1333. 